\title{
Biocompatible non-covalent complexes of chitosan and different polymers: characteristics and application in drug delivery
}

\author{
Ana Ćirić ${ }^{*}$, Danina Krajišnik ${ }^{1}$, Bojan Čalija ${ }^{1}$, Ljiljana Đekić $^{1}$ \\ ${ }^{1}$ University of Belgrade - Faculty of Pharmacy, Department of Pharmaceutical \\ Technology and Cosmetology, Vojvode Stepe 450, 11221 Belgrade, Serbia \\ *Corresponding author: Ana Ćirić, E-mail: ana.ciric001@gmail.com
}

\begin{abstract}
The formulation of biocompatible drug carriers based on cationic biopolymer chitosan and natural or synthetic polymers represents an important research interest. Therefore, this review aims to perceive their potential in drug delivery. The most investigated chitosan-based polymer blends are polyelectrolyte complexes (PECs) obtained by establishing ionic interactions with biocompatible polyanions as alginates, pectin, xanthan gum, carrageenan, carboxymethylcellulose, and collagen. Depending on the preparation conditions, PECs could be prepared in versatile forms including membranes/films, hydrogel beads, nanoparticles, and microparticles, to achieve controlled (e.g., extended, delayed, colon-specific and pH-dependent) drug delivery. PECs can encapsulate hydrophilic and lipophilic drug substances with different molecular weights. Drug encapsulation allows the preservation of their structure, activity, improvement in absorption efficiency, reduction in adverse effects and long-term stability in vitro and in vivo. The biocompatible structures as non-covalent chitosan-based complexes could be formed also by establishing hydrogen bonds, for example with poly(vinyl alcohol). The swelling of these complexes is not $\mathrm{pH}$-dependent and encapsulated drug substances are often released by already known types of diffusion. Moreover, grafted chitosan derivatives (e.g., carboxymethyl chitosan, trimethyl chitosan, acrylated chitosan) are synthesized to improve water solubility at a wide $\mathrm{pH}$ range and enhance the encapsulation capacity of promising PEC-based drug carriers.
\end{abstract}

Keywords: chitosan, polyelectrolyte complex, biocompatibility, drug carriers, controlled drug delivery 


\section{Introduction}

Numerous drug carriers are based on the combination of polymers, which may be covalently or non-covalently linked. Due to the toxicity of the reagents used for covalent bonding, current research interest is focused on polymer blends with non-covalent (ionic, hydrogen, hydrophobic) interactions between polymer chains (1).

Chitosan is the most commonly used natural cationic polymer obtained by deacetylation of chitin. Chitosan contains N-acetyl-D-glucosamine and D-glucosamine units with one amino and two hydroxyl groups in each glycoside unit (Fig. 1). At media $\mathrm{pHs}$ under chitosan $\mathrm{pKa}$ value, due to the protonation of amino groups, chitosan becomes positively charged which increases its solubility. The properties of chitosan as mucoadhesion, controlled drug delivery, in situ gelling, permeability enhancement, colon-specific drug delivery, inhibition of efflux pumps, etc. make it a suitable excipient for development of various pharmaceutical formulations (2-4). Chitosan per se is not convenient in designing the controlled-release drug delivery systems because it dissolves rapidly in the stomach at lower $\mathrm{pH}$ values. That is why it is often combined with anionic polymers (5-7).

The oppositely charged polyelectrolytes stay interconnected by establishing electrostatic (ionic) interactions whereby they form polyelectrolyte complexes (PECs) (Fig. 1) $(1,8)$. Ionic interactions are strong but reversible and their formation is a common approach to evade the use of potentially toxic cross-linkers. The reaction takes place at $\mathrm{pH}$ values close to the $\mathrm{pKa}$ values of the polyelectrolytes that form PEC. Upon the formation of ionic interactions, new bonds between the polymers are created and the proper spatial conformation is achieved, followed by the stabilization of the obtained PEC by establishing the hydrophobic bonds between polymer chains (8). During the PEC formation, polymers can form coacervates as a consequence of precipitation due to the strong interactions between oppositely charged polyions $(5,9)$. Precipitation can be prevented by the addition of salts, e.g., sodium chloride. The presence of ions reduces the attractive forces between the oppositely charged polymers, prevents phase separation, and ensures the formation of viscous and homogeneous gels (1). PEC-based carriers are principally considered biocompatible and well-tolerated. Moreover, they may be sensitive to changes in $\mathrm{pH}$ and/or ionic strength. The formation and stability of PECs depend on numerous factors, such are the ionization degree of the polymers, the charge distribution along the polymer chains, the concentration of polymers, polymer ratio in the mixture, the mixing order of polymers' dispersions (i.e., the addition of the dispersion of anionic polymer into the dispersion of cationic polymer, or vice versa), the polymer molecular weight, temperature, ionic strength, $\mathrm{pH}$ of the reaction medium. It is important to stress that stoichiometric PECs always have an even amount of positive and negative charge, resulting in zero net charge, and their water solubility is poor. However, with the addition of one polymer in excess to the polymer mixture, the water-soluble non-stoichiometric PECs are formed $(5,10-12)$ (Fig. 1). More recently, numerous PECs based on 
polysaccharides and proteins have been formulated as carriers for drug delivery, DNA delivery, or tissue engineering $(2,4,7)$. Many different polyanions have been used for the formation of PECs with chitosan, such as natural polymers and their semi-synthetic derivatives (e.g., alginates (13-18), pectin (19-23), xanthan gum (11, 12, 24-27), carrageenan (28-30), carboxymethylcellulose (31,32), collagen (25)), synthetic polymers and tripolyphosphate (TPP) (33) (Tab. I). Chitosan-based PECs can be obtained by various methods and therefore be of different shapes/geometries, including membranes/films (34-36), hydrogel beads $(24,37,38)$, nanoparticles and microparticles $(14,15,33,35,39-41)$ (Fig. 1). Since chitosan biocompatibility is retained after the formation of PECs, the application and safety of chitosan-based PECs are dependent on the used polyanions (7). The important characteristic of PECs is their sensitivity to $\mathrm{pH}$ changes. In the acidic environment, the polyanion is neutralized and amino groups of chitosan are protonated. The repulsion of positively charged chitosan chains in the presence of media leads to the swelling of the formed gel. In the alkaline media, the swelling occurs in the same manner, but it is induced by the repulsion of negative charge of the polyanion (11). As PECs swelling depends on numerous factors, modification of drug release from the carrier could be achieved (1).

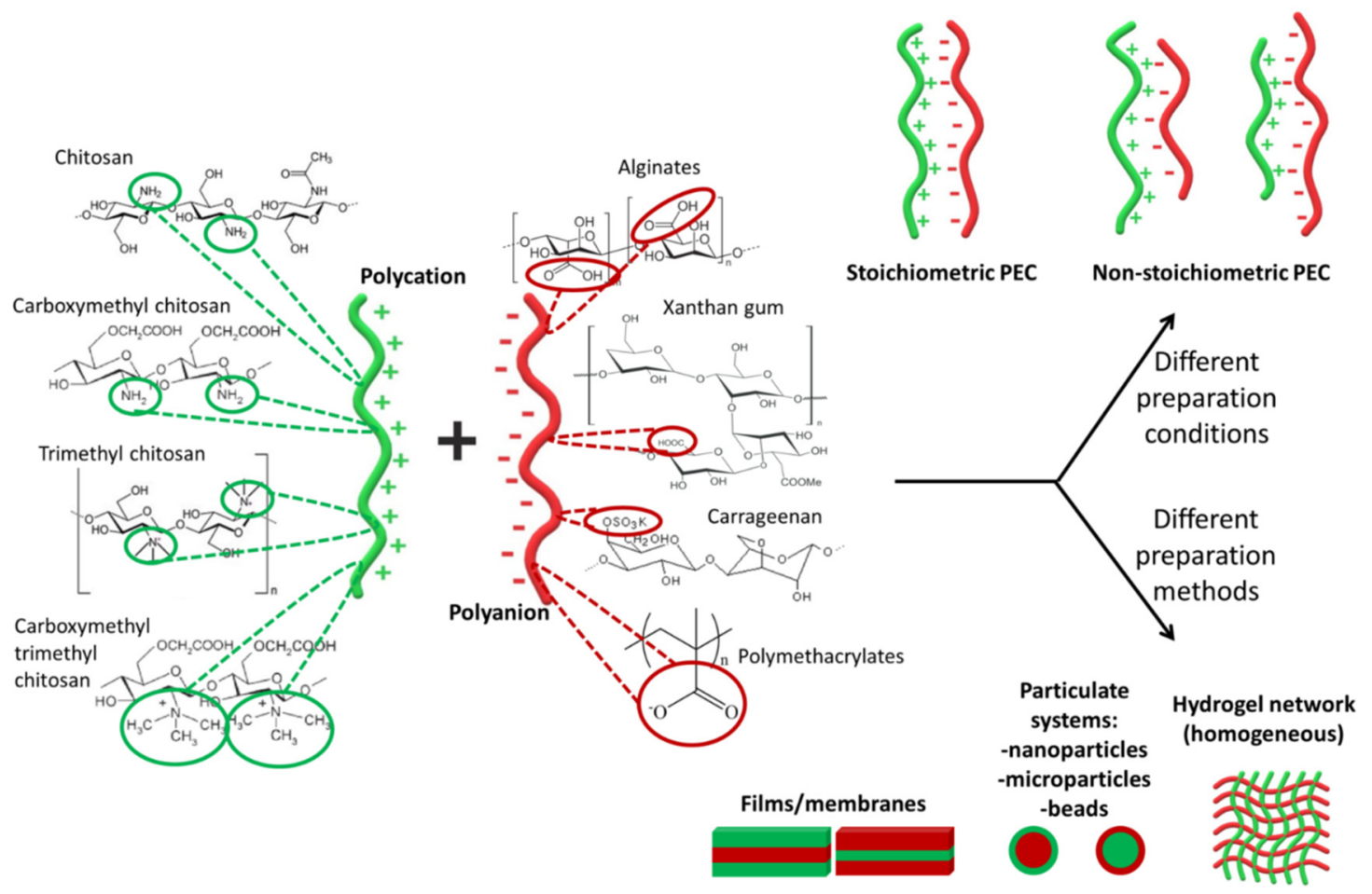

Figure 1. Schematic presentation of the formation and structure of different drug carriers obtained from chitosan-based PEC.

Slika 1. Shematski prikaz formiranja i strukture različitih vrsta nosača lekovitih supstanci dobijenih od PEK na bazi hitozana. 
Additionally, complexes similar to PECs can be formed by combining chitosan and polyvinyl alcohol (PVA), based on hydrogen bonds between the hydroxyl groups of PVA and the hydroxyl or amino groups of chitosan. These carriers are also biocompatible and have a potential for use in biomedicine. Complexes prepared by the autoclaving method can be used as scaffolds in cell culture, while complexes prepared by freeze/thaw method can be used as drug carriers (1).

The limitation of the use of chitosan in drug delivery is its insolubility at $\mathrm{pH}$ values higher than 6.5. Besides, chitosan per se has low drug entrapment capacity, limited ability to control drug release, and modest mucoadhesive properties. To overcome these limitations, chemically modified chitosan (grafted chitosan) have been synthesized and used in the formulation of drug delivery systems $(1,42,43)$.

\section{PECs of chitosan and natural polymers}

Many natural polymers (polysaccharides), owing to their biocompatibility and low toxicity, have been used in the formulation of chitosan-based PECs. The most commonly used anionic polysaccharide for the preparation of chitosan-based PEC drug carriers is alginate. Among other natural polyanions often used in the formulation of chitosan-based PECs are pectin, xanthan gum, carrageenan, hyaluronic acid, and gellan gum (7) (Tab. I). There are several other natural polysaccharides (and their semi-synthetic derivatives) that can form PECs with chitosan. Although they have not been extensively investigated as drug carriers so far, many of them have a certain potential: for colon-specific drug delivery $(44,45)$; gum kondagogu for improved oral delivery of diclofenac-sodium (46); carboxymethylated psyllium arabinoxylan for prolonged release of ibuprofen (47); ulvan for the preparation of matrices for enzyme-induced biomimetic bone mineralization (48); carboxymethyl gum katira for the prolonged of ofloxacin release (49); curdlan sulphate for controlled and $\mathrm{pH}$-dependent zidovudine release (50); carboxylic curdlan for sustained 5-fluorouracil delivery (51); carboxymethyl starch for extended paracetamol release (52).

\subsection{Chitosan/alginate-based PECs}

Alginates are natural linear and biodegradable polysaccharides containing 1,4linked $\beta$-D-mannuronic and $\alpha$-L-guluronic acid in different ratios (Fig. 1). Alginates are obtained by extraction from brown seaweed, Laminaria hyperborea, Ascophyllum nodosum, or Macrocystis pyrifera. Negatively charged carboxylate groups of mannuronic and guluronic acid in alginates can establish ionic interactions with positively charged amino groups of chitosan and form PECs $(1,5,7,53)$. Alginates are the most investigated anionic polyelectrolytes used for the formation of PECs with chitosan due to their biodegradability and biocompatibility $(18,37,54,55)$.

Even under mild reaction conditions, alginates can easily interact with divalent cations such as $\mathrm{Ca}^{2+}$ (the most commonly used), $\mathrm{Sr}^{2+}$, or $\mathrm{Zn}^{2+}$, which act as cross-linkers 
between the functional groups of alginate chains. Gelling occurs due to the formation of insoluble alginates when divalent cations form the bonds mostly between guluronic acid residues of alginate chains, which leads to the formation of a three-dimensional network (the "egg-box" structure). However, monovalent cations and $\mathrm{Mg}^{2+}$ ions cannot act as cross-linkers between alginate chains and gelation does not occur $(53,56,57)$. Two methods (external and internal) of alginate gelation with polyvalent cations are described by Chan et al. (58). In the external gelation method, an alginate/drug mixture is added directly to the calcium salt (e.g., calcium chloride) solution dropwise. In the internal gelation method, the mixture of alginate and drug substance is pre-mixed with insoluble calcium salt (e.g., calcium carbonate), and the mixture is then added to the acidified oily phase, resulting in the release of $\mathrm{Ca}^{2+}$ ions which interact with alginate. The alginate $/ \mathrm{Ca}^{2+}$ gels obtained by described methods often have a loose structure, which leads to the loss of drug substances throughout the gelling process, mostly water-soluble ones.

The chitosan/alginate-based PECs were prepared by various methods and in various forms, including nanoparticles, microparticles, beads/hydrogels, filaments/fibers, and 3D matrices. When compared with alginate gels obtained by calcium ions crosslinking or chitosan gels, PECs possessed significantly improved physicochemical properties $(2,7)$.

Drug carriers based on chitosan/alginate PECs are generally in the form of particles (nanoparticles, microparticles, beads), which depends on the preparation conditions, as well as the formulation itself. In order to prepare chitosan/alginate-based PECs in the form of particles, the external gelation method is commonly used. The preparation process can be carried out as a one-step and a two-step process. In a one-step process, alginate dispersion is slowly added to the dispersion of chitosan with or without $\mathrm{Ca}^{2+}$ ions, drop by drop. In a two-step process, an alginate-calcium gel is formed first and then added to the chitosan dispersion to form a PEC membrane around the alginate-calcium gel. Using both methods, particles of various sizes, from nanoparticles to beads of several hundred $\mu \mathrm{m}$ in diameter can be obtained, depending on the concentration of polymers and $\mathrm{Ca}^{2+}$ ions, polymers' molecular weight, and the charge density $(7,55,59,60)$. Many studies involve an additional step following the two-step procedure. It leads to an increase in the strength of the PEC membrane by adding TPP, polyanion that achieves electrostatic interactions with chitosan (61).

The net charge and polymers' molecular weight are considered the most important parameters that influence the physicochemical properties of chitosan/alginate-based PECs. To obtain the particles with a small diameter, one polyelectrolyte should be in excess $(55,60)$.

Wong et al. (61) formulated hydrogel beads based on chitosan/alginate PEC using the one-step process with the addition of TPP to increase the mechanical strength of the chitosan coating of beads and prevent their adhesion during drying (Tab. I). High concentrations ( $3 \%$ alginate, $4 \%$ calcium ions, and $0.5 \%$ chitosan) were used, which led to the preparation of beads with a large diameter $(1.7-1.9 \mathrm{~mm})$. Microwave irradiation 
was applied during the preparation, and sulfathiazole was selected as the model drug for encapsulation into beads. Microwave irradiation did not affect the chemical stability of sulfathiazole, but significantly extended its release in comparison with non-irradiated beads. The results showed that microwave irradiation can be used in the formulation of solid dosage forms for controlled drug delivery. Numerous studies have shown that different drying processes have a strong effect on particle morphology and drug release profiles from chitosan/alginate PEC-based particles. Air-dried beads retained a spherical shape and sponge-like structure with a smooth surface. Lyophilized beads lost a spherical shape and had a rough surface. Considering these structural differences, lyophilized beads had a higher swelling capacity, whereas air-dried beads showed delayed release of the drug in the simulated gastrointestinal tract. Given the possibility of industrial production and application in drug delivery, air-dried beads may have better characteristics than freeze-dried beads $(37,62)$.

Table I Examples of different chitosan-based PECs and their performances as drug delivery carriers.

Tabela I Primeri različitih PEK na bazi hitozana i njihova svojstva kao nosača lekovitih supstanci.

\begin{tabular}{|c|c|c|c|c|c|c|}
\hline Polyanion & Drug & $\begin{array}{l}\text { PEC type/ } \\
\text { dosage form }\end{array}$ & $\begin{array}{l}\text { Preparation } \\
\text { method }\end{array}$ & $\begin{array}{l}\text { Use/route of } \\
\text { administration }\end{array}$ & Effect on drug release & Ref. \\
\hline $\begin{array}{l}\text { Alginate }+ \\
\text { TPP }\end{array}$ & Sulphathiazole & $\begin{array}{l}\text { Hydrogel beads } \\
\text { (chitosan-coated) }\end{array}$ & $\begin{array}{c}\text { Extrusion } \\
\text { method }+ \\
\text { drying at } \\
40^{\circ} \mathrm{C}+ \\
\text { microwave } \\
\text { irradiation }\end{array}$ & $\begin{array}{l}\text { n.d. } \\
\text { (oral*) }\end{array}$ & $\begin{array}{l}\text { Controlled release of drug (in } \\
\text { comparison with non-irradiated } \\
\text { beads) }\end{array}$ & (61) \\
\hline Alginate & Vancomycin & $\begin{array}{l}\text { Microparticles } \\
\text { (alginate-coated) }\end{array}$ & $\begin{array}{l}\text { Coacervation } \\
\text { method }+ \text { air- } \\
\text { drying or } \\
\text { lyophilization }\end{array}$ & $\begin{array}{l}\text { Injectable } \\
\text { drug delivery } \\
\text { system }\end{array}$ & $\begin{array}{l}\text { Controlled (prolonged) release } \\
\text { during } 3 \text { weeks }\end{array}$ & (15) \\
\hline Alginate & Insulin & $\begin{array}{l}\text { Microparticles } \\
\text { (chitosan-coated) }\end{array}$ & $\begin{array}{l}\text { Membrane } \\
\text { emulsification } \\
\text { method }+ \\
\text { lyophilization }\end{array}$ & Oral & $\begin{array}{c}\text { In vitro: prolonged release } \\
\text { during } 14 \text { days, } \mathrm{pH} \text {-dependent } \\
\text { release } \\
\text { In vivo (in rats): hypoglycemic } \\
\text { effect during } 60 \mathrm{~h}\end{array}$ & (63) \\
\hline Alginate & $\begin{array}{l}\text { Ketotifen- } \\
\text { fumarate }\end{array}$ & $\begin{array}{l}\text { Membrane/film } \\
\text { (matrix type) }\end{array}$ & $\begin{array}{l}\text { Casting } \\
\text { method + air- } \\
\text { drying }\end{array}$ & Transdermal & $\begin{array}{l}\text { Enhanced drug permeability } \\
\text { through the skin }\end{array}$ & (16) \\
\hline $\begin{array}{l}\text { Alginate }+ \\
\text { PGA }\end{array}$ & Piroxicam & $\begin{array}{l}\text { Composite } \\
\text { hydrogel }\end{array}$ & $\begin{array}{c}\text { Semi- } \\
\text { dissolution/ } \\
\text { acidification/ } \\
\text { sol-gel } \\
\text { transition } \\
\text { method }\end{array}$ & Oral & $\begin{array}{l}\text { pH-dependent, prolonged (up to } \\
8 \mathrm{~h} \text { ) and colon-specific drug } \\
\text { delivery; reduced GIT irritation }\end{array}$ & (9) \\
\hline
\end{tabular}




\begin{tabular}{|c|c|c|c|c|c|c|}
\hline Polyanion & Drug & $\begin{array}{l}\text { PEC type/ } \\
\text { dosage form }\end{array}$ & $\begin{array}{l}\text { Preparation } \\
\text { method }\end{array}$ & $\begin{array}{c}\text { Use/route of } \\
\text { administration }\end{array}$ & Effect on drug release & Ref. \\
\hline $\mathrm{HA}+\mathrm{TPP}$ & $\begin{array}{l}\text { Dexamethasone } \\
\text { - sodium } \\
\text { phosphate }\end{array}$ & $\begin{array}{l}\text { Nanoparticles } \\
\text { (HA-coated) }\end{array}$ & $\begin{array}{l}\text { Ionic gelation } \\
\text { method }+ \\
\text { lyophilization }\end{array}$ & $\begin{array}{l}\text { Ocular } \\
\text { (topical) }\end{array}$ & $\begin{array}{l}\text { In vitro: sustained drug release } \\
\text { during } 12 \mathrm{~h}\end{array}$ & $(69)$ \\
\hline $\mathrm{HA}+\mathrm{TPP}$ & $\begin{array}{l}\text { Dexamethasone } \\
\text { - sodium } \\
\text { phosphate }\end{array}$ & $\begin{array}{l}\text { Nanoparticles } \\
\text { (HA-coated) }\end{array}$ & $\begin{array}{l}\text { Ionic gelation } \\
\text { method }+ \\
\text { lyophilization }\end{array}$ & $\begin{array}{l}\text { Ocular } \\
\text { (topical) }\end{array}$ & $\begin{array}{l}\text { In vivo (in rabbits): prolonged } \\
\text { retention in the eye, adequate } \\
\text { drug concentrations in aqueous } \\
\text { humor up to } 24 \mathrm{~h}\end{array}$ & $(70)$ \\
\hline HA & $\begin{array}{l}\text { Vancomycin, } \\
\text { insulin }\end{array}$ & $\begin{array}{l}\text { Bulk PEC/nasal } \\
\text { insert }\end{array}$ & $\begin{array}{l}\text { Complex } \\
\text { coacervation } \\
\text { method }+ \\
\text { lyophilization }\end{array}$ & $\begin{array}{l}\text { Nasal } \\
\text { (systemic } \\
\text { effect) }\end{array}$ & $\begin{array}{l}\text { Prolonged and } \mathrm{pH} \text {-dependent } \\
\text { release of both drugs during } 6 \mathrm{~h}\end{array}$ & $(71)$ \\
\hline Pectin (amide) & $\begin{array}{l}\text { Indomethacin, } \\
\text { sulfamethoxazole }\end{array}$ & $\begin{array}{l}\text { Hydrogel beads } \\
\text { (chitosan-coated) }\end{array}$ & $\begin{array}{c}\text { Extrusion } \\
\text { method }+ \\
\text { drying at } 50^{\circ} \mathrm{C}\end{array}$ & $\begin{array}{l}\text { n.d. } \\
\text { (oral*) }\end{array}$ & $\begin{array}{l}\mathrm{pH} \text {-dependent and prolonged } \\
\text { drug release (up to } 5 \mathrm{~h} \text { ) }\end{array}$ & $(81)$ \\
\hline Pectin & Resveratrol & $\begin{array}{l}\text { Nanoparticles } \\
\text { (chitosan-coated) }\end{array}$ & $\begin{array}{l}\text { Extrusion } \\
\text { method }\end{array}$ & $\begin{array}{l}\text { n.d. } \\
\text { (oral*) }\end{array}$ & Colon-specific drug release & $(23)$ \\
\hline Pectin & $\begin{array}{l}\text { Mesalamine, } \\
\text { curcumin, } \\
\text { progesterone }\end{array}$ & $\begin{array}{c}\text { Thermoreversible } \\
\text { hydrogels }\end{array}$ & $\begin{array}{l}\text { Complex } \\
\text { coacervation } \\
\text { method }\end{array}$ & $\begin{array}{c}\text { n.d. } \\
\text { (oral*) }\end{array}$ & $\begin{array}{c}\text { Sustained release of all } 3 \text { drugs } \\
\text { during } 24 \mathrm{~h} \text { at physiological } \\
\text { conditions }\end{array}$ & $(22)$ \\
\hline$\kappa$-carrageenan & Ovoalbumin & $\begin{array}{c}\text { Nanoparticles } \\
\text { (chitosan- } \\
\text { coated)/implants }\end{array}$ & $\begin{array}{l}\text { Ionic gelation } \\
\text { method }+ \\
\text { lyophilization }\end{array}$ & $\begin{array}{l}\text { Implantation } \\
\text { into the } \\
\text { affected area }\end{array}$ & $\begin{array}{l}\text { Controlled drug release } \\
\text { up to } 3 \text { weeks }\end{array}$ & $(86)$ \\
\hline $\begin{array}{c}\text { א-carrageenan } \\
+ \\
\text { hydroxyapatite }\end{array}$ & Ciprofloxacin & $\begin{array}{l}\text { Hydrogel } \\
\text { nanocomposites }\end{array}$ & $\begin{array}{l}\text { Mixing of } \\
\text { polymer } \\
\text { solutions }+ \\
\text { lyophilization }\end{array}$ & n.d. & $\begin{array}{l}\text { Sustained drug release during } \\
\qquad 120 \mathrm{~h}\end{array}$ & $(30)$ \\
\hline $\mathrm{XG}$ & Glipizide & $\begin{array}{c}\text { Floating } \\
\text { mucoadhesive } \\
\text { beads } \\
\text { (chitosan-coated) }\end{array}$ & $\begin{array}{c}\text { Complex } \\
\text { coacervation } \\
\text { method + air- } \\
\text { drying } \\
\text { Complex }\end{array}$ & Oral & $\begin{array}{l}\text { Controlled (sustained) and } \mathrm{pH}- \\
\text { dependent drug release during } \\
\qquad 24 \mathrm{~h}\end{array}$ & $(24)$ \\
\hline $\mathrm{XG}$ & Chlorohexidine & Microspheres & $\begin{array}{l}\text { method }+ \\
\text { lyophilization }\end{array}$ & $\begin{array}{l}\text { Periodontal } \\
\text { injection }\end{array}$ & $\begin{array}{l}\text { Prolonged drug release } \\
\text { up to } 7 \text { days }\end{array}$ & $(26)$ \\
\hline $\mathrm{XG}$ & Ibuprofen & Bulk PEC & $\begin{array}{l}\text { Complex } \\
\text { coacervation } \\
\text { method + air- } \\
\text { drying }\end{array}$ & Oral & $\begin{array}{l}\text { Extended drug release } \\
\text { up to } 10 \mathrm{~h}\end{array}$ & $(12)$ \\
\hline GG & Ketoconazole & $\begin{array}{l}\text { Nanoparticles } \\
\text { (chitosan-coated) }\end{array}$ & $\begin{array}{l}\text { Electrostatic } \\
\text { complexation } \\
\text { method }+ \\
\text { lyophilization }\end{array}$ & $\begin{array}{l}\text { n.d. } \\
\text { (topical*) }\end{array}$ & $\begin{array}{c}\text { Sustained drug delivery; } \\
\text { significantly higher antifungal } \\
\text { activity against } \text { Aspergillus } \\
\text { niger compared to pure drug }\end{array}$ & $(91)$ \\
\hline
\end{tabular}




\begin{tabular}{|c|c|c|c|c|c|c|}
\hline Polyanion & Drug & $\begin{array}{l}\text { PEC type/ } \\
\text { dosage form }\end{array}$ & $\begin{array}{l}\text { Preparation } \\
\text { method }\end{array}$ & $\begin{array}{c}\text { Use/route of } \\
\text { administration }\end{array}$ & Effect on drug release & Ref. \\
\hline $\mathrm{CMC}$ & Vancomycin & $\begin{array}{l}\text { Microparticles } \\
\text { (chitosan-coated) }\end{array}$ & $\begin{array}{l}\text { Complex } \\
\text { coacervation } \\
\text { method }+ \\
\text { spray-drying }\end{array}$ & $\begin{array}{l}\text { n.d. } \\
\text { (oral*) }\end{array}$ & $\begin{array}{c}\text { Colon-specific drug delivery; } \\
\text { prevention of drug degradation at } \\
\text { low pH and the presence of } \\
\text { pepsin }\end{array}$ & (32) \\
\hline $\begin{array}{l}\text { Poly acrylic } \\
\text { acid }\end{array}$ & Teophylline & $\begin{array}{l}\text { Bulk PEC/matrix } \\
\text { tablet }\end{array}$ & $\begin{array}{c}\text { Complex } \\
\text { coacervation } \\
\text { method }+ \\
\text { lyophilization }\end{array}$ & $\begin{array}{l}\text { n.d. } \\
\left(\text { oral }^{*}\right)\end{array}$ & $\begin{array}{l}\mathrm{pH} \text {-dependent and prolonged } \\
\text { drug delivery during } 12 \mathrm{~h}\end{array}$ & (93) \\
\hline $\begin{array}{c}\text { Eudragit }^{\circledR} \\
\text { S-100 }\end{array}$ & Curcumin & $\begin{array}{l}\text { Microparticles } \\
\text { (Eudragit }^{\mathbb{B}} \text {-coated) }\end{array}$ & $\begin{array}{l}\text { Emulsion } \\
\text { cross-linking }+ \\
\text { solvent } \\
\text { evaporation } \\
\text { method }+ \\
\text { drying at } 50^{\circ} \mathrm{C} \\
\end{array}$ & $\begin{array}{c}\text { n.d. } \\
\text { (oral*) }\end{array}$ & $\begin{array}{l}\text { In vitro: Controlled drug release } \\
\text { up to } 12 \mathrm{~h} \text { and prevention of } \\
\text { premature release } \\
\text { In vivo (in mice): colon-specific } \\
\text { drug delivery }\end{array}$ & (97) \\
\hline
\end{tabular}

n.d. - not defined; *conclusion based on experimental conditions (data) in the study; Abbreviations: CMC - carboxymethylcellulose; GG - gellan gum; GIT - gastrointestinal tract; HA - hyaluronic acid; PEC - polyelectrolyte complex; PGA - polyglutamic acid; TPP tripolyphosphate; XG - xanthan gum.

In another study chitosan/alginate PEC-based microparticles with vancomycin were prepared by the coacervation method and dried by lyophilization or air-dried. Lyophilized microparticles showed the best control of drug release with the average release of $22 \mu \mathrm{g} /$ day during 14 days. With an increase in alginate concentration, the vancomycin release rate did not increase. Drug release followed Peppas-Sahlin kinetics, with Fickian diffusion and case II relaxation release mechanisms (15) (Tab. I).

Encapsulation of macromolecular drug substances into PEC-based carriers with alginate aims at preserving their structure and biological activity, protect them from negative environmental factors, and improve absorption efficiency. To examine the encapsulation of proteins and their release, chitosan/alginate-based PECs are often prepared by the two-step process in a form of microparticles or beads. The delivery of insulin encapsulated into chitosan/alginate PEC-based microparticles after oral administration has been tested in vivo in rats (63) (Tab. I). It has been shown that encapsulated insulin was well protected from the effect of the gastrointestinal tract and easily absorbed in vivo. The effect of insulin released from microparticles was conserved during more than $60 \mathrm{~h}$, implying its long-term stability in vivo. Lefnaoui et al. (16) developed chitosan/alginate PEC-based matrix-type films for transdermal delivery of ketotifen fumarate (Tab. I). Films with different PEC compositions were prepared at various chitosan-to-sodium alginate ratios by the film casting method. Propylene glycol was used as a film plasticizer, and Tween ${ }^{\circledR} 80$ and $\operatorname{Span}^{\circledR} 20$ as permeation enhancers. 
The obtained results revealed no significant interaction between ketotifen and polymers. It was observed that when Tween ${ }^{\circledR} 80$ was used as a permeability enhancer, an adequate drug release profile was obtained (with $99.88 \%$ of the drug released) and $2.121 \mathrm{mg} / \mathrm{cm}^{2}$ of ketotifen permeated through rat abdominal skin after $24 \mathrm{~h}$. The optimal formulation had a permeability coefficient of $14.00 \pm 0.001 \mathrm{cmh}^{-1}$ and a lag time of $0.35 \pm 0.02 \mathrm{~h}$.

Recently, many other chitosan/alginate-based PECs with the addition of the third component were formulated. For example, chitosan/polyglutamic acid (PGA)/alginate PEC hydrogel was formulated to achieve better control of piroxicam release (9) (Tab. I). Mucoadhesiveness of chitosan/alginate-based PECs has been proven in various ex vivo models, such as isolated rat jejunum (64) and the proximal part of the porcine colon (65).

\subsection{Chitosan/hyaluronic acid-based PECs}

Hyaluronic acid (HA) is a natural non-toxic, biocompatible, and biodegradable polysaccharide, i.e., glycosaminoglycan with recurrent $\beta-1,4-\mathrm{D}$-glucuronic acid-1,3-Nacetyl-D-glucosamine disaccharide units. HA is present in all tissues, particularly in connective, epithelial, and nervous tissue, and has a high molecular weight, from $100 \mathrm{kDa}$ in serum to $8000 \mathrm{kDa}$ in the vitreous body. Because of the presence of carboxylate groups in its structure, HA is a natural anionic polyelectrolyte with the ability to form PECs with chitosan. Chitosan/HA-based PECs have a potential for application in biomedicine owing to their colloidal stability, low cytotoxicity, and ability to protect drugs from enzymatic degradation. By combining highly mucoadhesive properties of HA and chitosan permeability enhancement effect, chitosan/HA PEC-based carriers may be more suitable than many other carriers to deliver drugs via mucous membranes and enhance their intestinal absorption $(5,7,66)$.

Nanoparticle systems based on chitosan/HA PECs are considered suitable carriers for drug delivery via different administration routes. For example, chitosan/HA nanoparticles are used for the ocular delivery of drugs without exhibiting eye discomfort or irritation (67).

Furthermore, enhanced mucoadhesion with improved pharmacodynamics of loaded drugs and reduced systemic absorption in an animal model was reported (68). Dexamethasone-sodium phosphate (DEX)-loaded chitosan-sodium tripolyphosphate nanoparticles (CS-NPs) were prepared using the ionotropic gelation method and coated with HA to obtain discrete, free-flowing NPs which would improve their mucoadhesion onto corneal and conjunctival epithelial surfaces and extend the drug retention in the eyes. Physicochemical characteristics of DEX-CS-NPs suspensions were appropriate for ocular use, with good stability for 3-months storage, while the size of NPs was increased from 305 to $400 \mathrm{~nm}$ after coating with HA. In vitro drug release testing in simulated tear fluid demonstrated that $75.84 \%$ of DEX was released during $12 \mathrm{~h}$ from HA-coated CS-NPs (69) (Tab. I). In vitro transcorneal permeation on the excised rabbit cornea and in vivo 
ocular irritation tests indicated the ocular safety of DEX-loaded HA-CS-NPs (70) (Tab. I).

The preparation of nasal inserts based on chitosan/HA PECs with mucoadhesive properties for nasal drug delivery was also reported (71) (Tab. I). In vitro swelling, mucoadhesion, and drug release investigations were done to evaluate the potential of vancomycin and insulin delivery in the nasal cavity. The obtained results revealed that the selection of suitable preparation conditions enabled the modification of insert swelling and prolonged drug release during $6 \mathrm{~h}$. Sponges or films based on chitosan/HA PECs for wound treatment were also reported (72-74).

Lalevée et al. (75) obtained chitosan/HA-based PECs in a homogeneous mixture of polymers at high salt concentrations. Then, the mixture was dialyzed, which led to the controlled self-assembly of the polymers. The assembly of chitosan and HA during the PEC formation depended mostly on chitosan acetylation degree and molar mass, the residual salt concentration, and the molar ratio of the charge of both polymers. These parameters determined if the obtained PECs will be in the form of colloidal suspensions or gel coacervates.

Nath et al. (76) loaded bone morphogenetic protein-2 (BMP-2) in chitosan/HAbased PEC. Free amino groups of chitosan were cross-linked with different amounts of genipin. Immobilization of BMP-2 (immobilization efficacies varied from $61 \%$ to $76 \%$, depending on the amount of BMP-2) in chitosan/HA PEC-based scaffolds sustained the protein release for more than 30 days. Moreover, BMP-2 facilitated osteogenesis. Thus, genipin cross-linked chitosan/HA PEC showed the potential in drug and protein delivery.

\subsection{Chitosan/pectin-based PECs}

Pectin is among the main components of the cell walls of plants. The chemical structure of pectin is highly miscellaneous and complex but is essentially rich in 1,4-galactosyluronic acid residues, and the linear chain is composed of acetyl and methyl esters of carboxylic acids. The degree of methyl esterification and the degree of acetylation determine pectin's functional properties, especially the ability to form a gel $(5,7,77)$. Pectin has been tested for the encapsulation and delivery of drugs, especially for colon-specific drug delivery $(78,79)$. Pectin molecules remain chemically unchanged under physiological conditions in the stomach and small intestine but can be degraded due to the action of enzymes of microbiota present in the colon. Due to its high solubility, pectin itself cannot be an effective drug carrier. Therefore, the coating of pectin and lowsoluble pectin derivatives (e.g., calcium-pectinate, pectin-amide) have been used to formulate pectin-based carriers $(77,80)$. Chitosan is the most prominent biopolymer in the development of pectin-based PEC carriers for the controlled drug release. Strong electrostatic coupling prevents gastric dissolution and provides high resistance to enzymatic hydrolysis, enabling the controlled release of drugs when the carrier reaches the colon $(5,7,77)$. 
The potential of chitosan coating in the modification of drug release from pectinamide-based hydrogels was investigated (81) (Tab. I). The release rate of indomethacin (highly lipophilic drug) and sulfamethoxazole (less lipophilic drug) from PECs after oral administration was significantly reduced compared to the pectin hydrogel without chitosan coating. Thus, encapsulation into chitosan-coated pectin-based hydrogel beads reduced the premature release of drugs in the gastrointestinal tract (GIT) and ensured their release in the colon. The $\mathrm{pH}$ of chitosan dispersion influenced the electrostatic interaction strength between pectin and chitosan, and $\mathrm{pH} 5.0$ was considered optimal. Additionally, it was demonstrated that the encapsulation efficiency of drugs, the swelling ability, and release profiles of drugs from chitosan/pectin based PECs, depended on various preparation factors, the acetylation degree, molecular weight, and methyl esterification degree of pectin $(82,83)$.

Chitosan/pectin/zinc-based particles with a diameter of approximately $1000 \mu \mathrm{m}$ were formulated for colon-specific delivery of resveratrol (84). Formulations prepared at a lower $\mathrm{pH}$ and a higher chitosan concentration significantly retarded resveratrol release in the simulated GIT in vitro. Further investigations of the drug pharmacokinetics in rats were performed to evaluate the effect of chitosan coating on the alteration in drug release. Even though the area under the curve and the maximum drug concentration were similar for the pectin/zinc and chitosan/pectin/zinc particles, the two formulations showed a significantly different drug retention profile in plasma. The stable period of plasma drug concentration growth was $2-4 \mathrm{~h}$ for pectin/zinc particles and $4-9 \mathrm{~h}$ for chitosan/pectin/zinc particles. Considering that it takes approximately $5-6 \mathrm{~h}$ for the drug to reach the colon, chitosan/pectin/zinc particles were considered more suitable than pectin/zinc particles for colon-specific resveratrol delivery.

In another study, the formulation of chitosan/zinc/pectinate/polyethylene glycol (PEG) nanoparticles for colon-specific delivery of resveratrol was investigated (23) (Tab. I). Size and zeta potential of nanoparticles obtained at pectin/zinc/chitosan ratio 10:1:3\% $w / v$ were $399 \pm 18 \mathrm{~nm}$ and $+25 \pm 1 \mathrm{mV}$, respectively. The addition of PEG (a solvent for resveratrol) significantly lowered the size of nanoparticles to $83 \pm 4 \mathrm{~nm}$. The encapsulation efficiency of resveratrol into nanoparticles with PEG was approximately $63 \%$, while for physically-loaded resveratrol (without PEG) was $26 \%$. A low amount of drug (approximately 40\%) was released from the nanoparticles without PEG during one month period at $\mathrm{pH} \mathrm{4}$, and the addition of PEG increased the released amount of drug to approximately $51 \%$. The remaining resveratrol in both types of nanoparticles was released in simulated colon fluid in the presence of pectinase, so they could be considered suitable for successful colon-specific delivery of resveratrol.

Neufeld et al. (22) investigated the suitability of chitosan/pectin hydrogels as drug carriers (Tab. I). Extended release of mesalamine, curcumin, and progesterone during 24 $\mathrm{h}$ under physiological conditions was demonstrated. FTIR and DSC experiments, as well as swelling analysis, showed that the interaction extent significantly affected drug release 
rates. Thus, it could be expected that the obtained chitosan/pectin hydrogels may reduce the frequency of drug intake.

\subsection{Chitosan/carrageenan-based PECs}

Carrageenan is a biopolymer obtained from red seaweed. It consists of galactose and anhydrogalactose linked by glycosidic bonds (Fig. 1). Depending on the method and source of extraction, there are three types of carrageenan, kappa $(\kappa)$, iota $(1)$ and lambda $(\lambda)$, which generally differ in the sulphate group substitution degree, and only $\kappa-$ and $1-$ carrageenan form gels. The first forms gels that are firm and rigid, and the second forms soft and elastic gels. Owing to the presence of sulphate groups, carrageenan is negatively charged and has the potential to interact with chitosan $(5,7,85)$.

Different chitosan/carrageenan PEC-based carriers, such as hydrogels (28), films (29), nanoparticles $(39,86)$, for different routes of administration and controlled release of drugs have been developed. Many factors can affect the physicochemical properties of these PECs, and the type of carrageenan, the mass ratio of the polymers, the solvent type used in the formulation, and ionic strength of the medium are the most important $(7,85)$.

At lower concentrations of chitosan and carrageenan, nanoparticles can be formed using the ionic gelation method and their surface charge depends on the mass ratio and the mixing order of polymers. Highly positively charged nanoparticles $(+60 \mathrm{mV})$ were obtained by the addition of the low concentration carrageenan dispersion into the chitosan dispersion dropwise. They showed good potential as drug carriers with no cytotoxicity at the concentrations up to $3 \mathrm{mg} / \mathrm{ml}$, which was confirmed on L929 fibroblast culture (86) (Tab. I). Rodrigues et al. (39) showed that the addition of TPP into carrageenan dispersion before its addition into chitosan dispersion significantly reduced the particle size from $500 \mathrm{~nm}$ to $200 \mathrm{~nm}$ and increased the yield from 20\% to 35\%. Maciel et al. (28) prepared chitosan/l-carrageenan superabsorbent hydrogels at different $\mathrm{pH}$ values (from 4 to 9 ) and different ratios of polysaccharides $(1: 1,1: 2$ and 2:1), with swelling degrees greater than $1000 \%$. The hydrogel surface was irregular, rough, and porous. The mechanical tests demonstrated that the hydrogels prepared at $\mathrm{pH} 4$ had greater compression strength compared to those prepared at $\mathrm{pH}$ 9. Chitosan/hydroxyapatite/ $\kappa$-carrageenan hydrogel nanocomposites for sustained release of ciprofloxacin with antibacterial activity against Gram-positive (Staphylococcus aureus) and Gram-negative (Escherichia coli) bacteria were also developed recently (30) (Tab. I). The chitosan/ $/$-carrageenan complex released $98 \%$ of ciprofloxacin throughout $120 \mathrm{~h}$, and only $52 \%$ and $66 \%$ of ciprofloxacin were released from nanocomposites containing high and low content of hydroxyapatite, respectively. For that reason, such nanocomposites could be considered as drug delivery systems with extended-release ability. 


\subsection{Chitosan/xanthan gum-based PECs}

Xanthan gum $(\mathrm{XG})$ is a natural anionic polyelectrolyte produced by Xanthomonas campestris, which contains five repeating sugar units: the backbone consists of two $\beta$-Dglucose units, and the sidechains include two mannose units and one glucuronic acid (Fig. 1). The sidechains have pyruvic acid residues attached to approximately one half of the terminal D-mannose units and acetic acid residues attached to D-mannose units in the backbone. XG is known for its non-toxicity and suitability for the development of drug carriers $(5,7,87)$.

Chitosan/XG hydrogel beads with high swelling ability are usually prepared by adding the concentrated $\mathrm{XG}$ dispersion dropwise into the chitosan dispersion. Network density and swelling capacity have been shown to depend more on the XG concentration and the $\mathrm{pH}$ of the medium than on the chitosan concentration. The high molecular weight of chitosan also led to a higher swelling degree of beads $(11,88)$.

Kulkarni et al. (24) prepared the floating mucoadhesive chitosan/XG beads by polyionic complexation technique for controlled release of glipizide with $\mathrm{pH}$-dependent swelling kinetics (Tab. I). Sustained in vitro release of $87.50-100.67 \%$ of glipizide after $24 \mathrm{~h}$, in phosphate buffer $\mathrm{pH} 7.4$, was observed. Encapsulation efficiency was between 79.48 and $94.48 \%$. In vitro bioadhesion studies showed that the beads had satisfactory bioadhesive strength.

Chitosan/XG based microspheres could be also prepared by the coacervation technique. The prepared microspheres were mixed with chlorohexidine (local antiseptic) to form injectable antibacterial hydrogels. The study of Kim et al. confirmed that prepared microspheres were biocompatible and had the potential in the treatment of acute or chronic periodontitis (26) (Tab. I).

Very recently, Ćirić et al. (12) studied the combined effect of $\mathrm{pH}$ adjusting agent type (hydrochloric, acetic or lactic acid) and $\mathrm{pH}$ value (3.6, 4.6 and 5.6) on the formation of chitosan/XG PECs, their characteristics and influence on in vitro ibuprofen release kinetics (Tab. I). Conductivity measurements and rheological characterization demonstrated the greatest interaction extent in PECs prepared with acetic acid at $\mathrm{pH}$ 3.6. Acid type and $\mathrm{pH}$ strongly influenced the yield and particle size of air-dried PECs. DSC, FTIR, and PXRD analysis confirmed exclusively physical interactions between the polymers. PECs comprising acetic acid prepared at $\mathrm{pH} 4.6$ and 5.6 improved rehydration capacity in phosphate buffer $\mathrm{pH}$ 7.2. At PEC-to-drug mass ratio up to 1:2, they prolonged ibuprofen release up to $10 \mathrm{~h}$.

De Morais Lima et al. (89) prepared six formulations of chitosan/XG based films using the casting technique and varying the chitosan-to-XG ratio at 100:0, 90:10, 80:20, 70:30, 60:40 and 50:50 (\%w/w). The films with a higher content of XG showed the highest tensile strength, while the addition of XG did not affect the water permeability, 
solubility, and residual moisture content of films. These results confirmed the formation of chitosan/XG PECs in the films.

A relatively new approach was proposed for the preparation of macroporous chitosan/XG PECs, cryogels, starting with the freezing of polymers' dispersion, maintaining it frozen during an appropriate period to enable the gel to freeze and form pores and then followed by lyophilization. First, XG powder is added to the concentrated dispersion of chitosan in dilute acetic acid solution, followed by freezing and then lyophilization. The electrostatic interactions between chitosan and XG enhanced during freezing, and therefore the gel was formed at a temperature below freezing temperature. The freezing method and its rate are considered the main parameters in defining the physicochemical characteristics of cryogels. A higher freezing rate $\left(-2^{\circ} \mathrm{C} / \mathrm{min}\right)$ led to the formation of smaller pores $(40 \mu \mathrm{m})$, while a lower freezing rate $\left(-0.25{ }^{\circ} \mathrm{C} / \mathrm{min}\right)$ resulted in the formation of larger pores $(68 \mu \mathrm{m})(90)$.

\subsection{Chitosan/gellan gum-based PECs}

Gellan gum (GG) is a biocompatible natural polymer produced by Pseudomonas elodeac which contains the residues of glucose, glucuronic acid, and rhamnose in 2:1:1 ratio. Due to the high content of glucuronic acid (20\%), GG is negatively charged when dissolved in water and its gelation is temperature-dependent (7).

Kumar et al. (91) prepared ketoconazole loaded chitosan/GG nanoparticles by electrostatic complexation technique (Tab. I). It has been shown that the influence of GG on the particle size was greater in comparison with chitosan. An increase in GG concentration significantly increased the particle size but decreased the zeta potential. On the contrary, an increase in chitosan concentration increased the zeta potential. The optimal formulation was obtained at a chitosan concentration of $0.02 \% w / v$ and GG of $0.01 \% \mathrm{w} / v$ with particle size and zeta potential of $155.7 \pm 26.1 \mathrm{~nm}$ and $32.1 \pm 2.8 \mathrm{mV}$, respectively. Ketoconazole-loaded nanoparticles had significantly higher antifungal activity against Aspergillus niger compared to drug-free nanoparticles and pure drug.

\section{PECs of chitosan and carboxymethylcellulose}

Among cellulose ethers, carboxymethylcellulose (CMC) has been the most investigated one for the utilization in biomedicine. CMC is a water-soluble polymer with a long linear cellulose chain and carboxymethyl groups attached to some hydroxyl groups of glucopyranose units. CMC is often in the form of sodium salt, so it carries a negative charge upon dissociation of the carboxylic groups when dissolved in water (7).

Temperature-sensitive and $\mathrm{pH}$-sensitive chitosan/CMC PEC-based hydrogel was evaluated as a carrier for parenteral delivery of drugs/cells. The hydrogel was prepared by mixing chitosan with a $\mathrm{CMC} /$ sodium hydrogen carbonate mixture at room temperature. The resulting PEC had liquid consistency at room temperature and the ability to encapsulate live chondrocytes. PEC gel implants were formed in situ, at body 
temperature and physiological $\mathrm{pH}$ after injection. This temperature-sensitive and $\mathrm{pH}-$ sensitive hydrogel had a great potential in bone and cartilage regeneration, due to the ability of in situ gel formation and controlled release of drugs/cells at a specific site after injection (92).

Bigucci et al. (31) prepared vaginal inserts based on chitosan/CMC PECs for local delivery of chlorhexidine digluconate at different chitosan/CMC molar ratios and $\mathrm{pH}$ around $\mathrm{pKa}$ interval of the polymers. PECs had high values of drug loading and increasing water uptake capacity with an increase in the $\mathrm{CMC}$ amount. The selection of adequate chitosan/CMC ratio (10:90) allowed the formulation of cone-like shaped solid inserts, that were easy to handle and able to hydrate, in addition to prolonged drug release during $6 \mathrm{~h}$. Moreover, the obtained inserts showed antimicrobial activity against Candida albicans and Escherichia coli.

On the other hand, Cerchiara et al. (32) prepared chitosan/CMC-based PECs for colon-specific delivery of vancomycin (Tab. I). Different formulations of PECs, with different chitosan/CMC mass ratios (3:1, 1:1 and 1:3), were prepared and collected in the form of microparticles by spray-drying. The best formulation prepared at chitosan/CMC mass ratio 1:3 was selected considering the encapsulation efficiency, water uptake, and drug release rate. Also, microparticles could prevent vancomycin degradation and had good antibacterial activity against Staphylococcus aureus.

\section{PECs of chitosan and synthetic polymers}

\subsection{Chitosan/polyacrylic acid-based PECs}

Polycarbophils and carbomers are high molecular weight polymers containing acrylic acid monomers and are formed by cross-linking the polyacrylic acid chains with divinyl glycol and polyhydroxy alcohols (e.g. allyl ethers of pentaerythritol, and allyl ethers of sucrose), respectively (5).

The main complexation mechanism between chitosan and carbomer is the formation of ionic interactions between amino groups of chitosan and carboxylate groups of carbomer, as confirmed by FTIR analysis. The chitosan-to-carbomer mass ratio and the preparation medium $\mathrm{pH}$ strongly influenced the characteristics of PECs. The release of drugs from matrix tablets based on chitosan/carbomer PECs at different ratios showed no significant differences at $\mathrm{pH} 1.2$, while they were strikingly observed at $\mathrm{pH} 6.8$ (93) (Tab. I). The chitosan/polycarbophil PEC-based matrix tablets showed zero-order release kinetics for two model drugs with different water solubility (diltiazem and ibuprofen). Their release rate depended on the concentration of PEC in the formulation. In general, chitosan/polycarbophil PECs have great potential as excipients for the formulation of modified-release dosage forms (94).

Recently, He et al. (95) formulated novel PEC hydrogels based on chitosan and sodium polyacrylate by cross-linking the polymers with epichlorohydrin, by inhibiting 
the protonation effect of chitosan in alkali/urea aqueous solution. The equilibrium swelling ratio of chitosan hydrogel in water increased significantly with the introduction of sodium polyacrylate. PEC hydrogel had different swelling ratios at different $\mathrm{pH}$ and ionic strength, leading to smart responsive properties. Also, PEC hydrogels had relatively high compressive strength, biocompatibility, and in vitro biodegradability.

\subsection{Chitosan/polymethacrylate copolymers-based PECs}

Polymethacrylate copolymers $\left(\right.$ Eudragit $\left.^{\circledR}\right)$ are commonly used as coating agents for capsules and tablets. There are different types of Eudragit ${ }^{\circledR}$, consisting of dimethylamino ethyl methacrylates, methacrylic acid esters, and methacrylic acid in different ratios. Some of them are positively charged $\left(\right.$ Eudragit $^{\circledR} \mathrm{E}, \mathrm{RL}, \mathrm{RS}$, and NE) owing to dimethylamino or quaternary amino groups, and the others are negatively charged (Eudragit ${ }^{\circledR} \mathrm{L}$ and $\mathrm{S}$ ) owing to carboxylate groups in their structure (5) (Fig. 1). PECs of different molecular weight chitosan and Eudragit ${ }^{\circledR}$ L100 or Eudragit ${ }^{\circledR}$ L100-55 were used to formulate matrix tablets with diclofenac-sodium. PECs of these two polymers had high potential in controlled drug delivery applications. The mass ratio of polymers and chitosan molecular weight influenced the drug release rate from matrix tablets (96). Sareen et al. (97) prepared Eudragit ${ }^{\circledR}$ S-100-coated chitosan microspheres with curcumin for the treatment of ulcerative colitis using the emulsion cross-linking method (Tab. I). Microspheres had a uniform spherical shape and high entrapment efficiency. Uncoated curcumin/chitosan microspheres exhibited in vitro burst release within the initial $4 \mathrm{~h}$. Eudragit ${ }^{\circledR}$ S-100 coating prevented the premature release of curcumin and enabled its controlled release during $12 \mathrm{~h}$. In vivo study in mice demonstrated their effectiveness and revealed a significant reduction of colonic damage with curcumin loaded into microspheres in comparison with pure curcumin. The obtained microspheres are considered the promising system for colon-specific curcumin delivery.

\section{Biocompatible chitosan/PVA complexes}

Biocompatible chitosan/PVA complexes are similar to PECs in terms of structure, characteristics, and use. However, they are formed mainly by the formation of hydrogen bonds between hydroxyl or amino groups of chitosan and hydroxyl groups of PVA (1). They can be readily prepared using different methods, such as the autoclaving method (98) and the freeze/thaw method (99-101). The structure of complexes could be different depending on the preparation method. PVA is a non-toxic, biodegradable, and biocompatible synthetic polymer that consists mainly of 1,3-glycol units and a small percentage of 1,2-glycol units (1). The complexes prepared by the autoclaving method are formed by mixing and autoclaving the PVA and chitosan dispersions to form highly elastic hydrogels (98). Hydrogels obtained by the freeze/thaw method are formed by repeating the freezing and thawing cycles of chitosan and PVA dispersions (99-101). Complexes prepared by the autoclaving method can be dissolved under acidic conditions 
and are not suitable as drug carriers. Complexes prepared by the freeze/thaw method are less soluble. The swelling of these complexes is not $\mathrm{pH}$-dependent, drug release is controlled by one of the already known types of diffusion and depends on chitosan mass content. Therefore, these chitosan/PVA hydrogels are promising drug carriers. Characteristics of chitosan favour the carrier adhesion to the application site and increase the bioavailability of low-permeable drugs after oral administration of chitosan/PVA gel (1, 98-101). Wu et al. (36) prepared chitosan/PVA based films by simple mixing and casting method. It was shown that chitosan and PVA in films interacted by intermolecular hydrogen bonds and complex based films had higher thermal stability than those made only of PVA. Chitosan addition decreased the tensile strength and light transmittance of films. The film with chitosan-to-PVA mass ratio 60:40 (\% w/w) showed notable activity against the adhesion and inhibited the growth of Pseudomonas aeruginosa.

\section{PECs of grafted chitosan and different polymers}

Chitosan derivatives are formed by substitution of some amino and/or hydroxyl groups in their structure (43). The preparation of derivatives often requires the use of auxiliary molecules to initiate the reaction. Grafting is usually performed with molecules that have functional groups that form covalent bonds with chitosan (1).

Chitosan copolymerization with hypromellose via coupling reagent-mediated approach to form a non-toxic chitosan derivative soluble in water, which was then complexed with CMC to form a PEC hydrogel, was successfully performed. When compared with conventional chitosan, the grafted chitosan had a high solubility at a wide $\mathrm{pH}$ range and higher buffering capacity, which provided a $\mathrm{pH}$-stable environment for drug delivery. Also, grafted chitosan-based PEC had the drug encapsulation efficiency of more than $90 \%$ (almost twice the encapsulation efficiency of chitosan-based PECs), with 2-3 times extended drug release (42).

PEC hydrogels based on carboxymethyl chitosan (CMCS) (Fig. 1) and alginate with high hygroscopicity were prepared. The hydrogels' swelling ratio could be increased 450 times by changing the CMCS-to-alginate mass ratio. Superabsorbent hydrogels were prepared at CMCS-to-alginate mass ratio below 1 . The in vitro cytotoxicity test showed that hydrogels had very high cytocompatibility. Their swelling ratio and bovine serum albumin (BSA) release were $\mathrm{pH}$-dependent. The hydrogels' swelling ratio (CMCS-toalginate mass ratio 1:2) at $\mathrm{pH} 7.4$ was about 34 times higher than at $\mathrm{pH} 1.2$, and the BSA released amount at $\mathrm{pH} 7.4$ was also significantly higher. The obtained CMCS/alginate PEC hydrogels had a high potential in oral delivery of proteins (43).

\section{Conclusion}

With the growing need for drug carriers of natural origin, PECs based on chitosan and natural polysaccharides are of increasing interest. The functional characteristics of these PECs can be adapted for various administration routes using different preparation 
methods and appropriate combinations with other polysaccharides. Recent research in this area highlights the following opportunities in the development of PECs based on chitosan and other polysaccharides: (1) design of various types of PECs such as nanoparticles, microparticles, hydrogel beads, gels, films and membranes, and optimization of drug release kinetics; (2) encapsulation of various drugs, including small molecules, macromolecular drugs, growth factors, antimicrobial agents, and achieving their controlled delivery; (3) improved mechanical properties, controlled swelling, and site-specific drug delivery. Most of the available literature deals with ionic interactions of chitosan, which are easily formed. Hydrogen bonds and hydrophobic interactions have been less studied and rarely used to achieve controlled drug release. This opened the space for more detailed investigations.

To our best knowledge, there are still no commercially available drug delivery systems based on complexes of chitosan with different polymers. On the other hand, there are many chitosan-based medical devices for wound healing, nutraceuticals, and cosmetic products on the market. Also, a drug for the treatment of onychomycosis, a nail lacquer with ciclopirox that contains a chitosan derivative (hydroxypropyl chitosan), is available on the market. Possible explanations for the absence of drug delivery systems based on complexes of chitosan with different polymers are strict regulatory aspects related to the pharmaceutical industry and a clear need to demonstrate their safety as pharmaceutical excipients. Fulfilment of these requirements can take a long time, but in the close future, such preparations may be launched onto the market, taking into account patients' needs unsatisfied with conventional drugs.

\section{Acknowledgements}

This work was supported by the Ministry of Education, Science and Technological Development of the Republic of Serbia (Number: 451-03-68/2020-14/200161).

\section{References}

1. Berger J, Reist M, Mayer JM, Felt O, Gurny R. Structure and interactions in chitosan hydrogels formed by complexation or aggregation for biomedical applications. Eur J Pharm Biopharm. 2004;57(1):35-52.

2. Muxika A, Etxabide A, Uranga J, Guerrero P, de la Caba K. Chitosan as a bioactive polymer: Processing, properties and applications. Int J Biol Macromol. 2017;105:1358-68.

3. Ali A, Ahmed S. A review on chitosan and its nanocomposites in drug delivery. Int J Biol Macromol. 2018;109:273-86.

4. Shariatinia Z. Pharmaceutical applications of chitosan. Adv Colloid Interface Sci. 2019;263:131-94.

5. Hamman JH. Chitosan based polyelectrolyte complexes as potential carrier materials in drug delivery systems. Mar Drugs. 2010;8(4):1305-22. 
6. Bhattarai N, Gunn J, Zhang M. Chitosan-based hydrogels for controlled, localized drug delivery. Adv Drug Deliv Rev. 2010;62(1):83-99.

7. Luo Y, Wang Q. Recent development of chitosan-based polyelectrolyte complexes with natural polysaccharides for drug delivery. Int J Biol Macromol. 2014;64:353-67.

8. De Robertis S, Bonferoni MC, Elviri L, Sandri G, Caramella C, Bettini R. Advances in oral controlled drug delivery: The role of drug-polymer and interpolymer non-covalent interactions. Expert Opin Drug Deliv. 2015;12(3):441-53.

9. Chen Y, Yan X, Zhao J, Feng H, Li P, Tong Z, et al. Preparation of the chitosan/poly(glutamic acid)/alginate polyelectrolyte complexing hydrogel and study on its drug releasing property. Carbohydr Polym. 2018;191:8-16.

10. Martínez-Ruvalcaba A, Chornet E, Rodrigue D. Viscoelastic properties of dispersed chitosan/xanthan hydrogels. Carbohydr Polym. 2007;67(4):586-95.

11. Argin-Soysal S, Kofinas P, Lo YM. Effect of complexation conditions on xanthan-chitosan polyelectrolyte complex gels. Food Hydrocoll. 2009;23(1):202-9.

12. Ćirić A, Medarević Đ, Čalija B, Dobričić V, Mitrić M, Djekic L. Study of chitosan/xanthan gum polyelectrolyte complexes formation, solid state and influence on ibuprofen release kinetics. Int $\mathrm{J}$ Biol Macromol. 2020;148:942-55.

13. Khong TT, Aarstad OA, Skjåk-Bræk G, Draget KI, Vårum KM. Gelling concept combining chitosan and alginate - Proof of principle. Biomacromolecules. 2013;14(8):2765-71.

14. Čalija B, Cekić N, Savić S, Daniels R, Marković B, Milić J. PH-sensitive microparticles for oral drug delivery based on alginate/oligochitosan/Eudragit ${ }^{\circledR}$ L100-55 "sandwich" polyelectrolyte complex. Colloids Surfaces B Biointerfaces. 2013;110:395-402.

15. Unagolla JM, Jayasuriya AC. Drug transport mechanisms and in vitro release kinetics of vancomycin encapsulated chitosan-alginate polyelectrolyte microparticles as a controlled drug delivery system. Eur J Pharm Sci. 2018;114:199-209.

16. Lefnaoui S, Moulai-Mostefa N, Yahoum MM, Gasmi SN. Design of antihistaminic transdermal films based on alginate-chitosan polyelectrolyte complexes: characterization and permeation studies. Drug Dev Ind Pharm. 2018;44(3):432-43.

17. Wasupalli GK, Verma D. Molecular interactions in self-assembled nano-structures of chitosansodium alginate based polyelectrolyte complexes. Int J Biol Macromol. 2018;114:10-7.

18. Gallardo-Rivera R, de los Ángeles Aguilar-Santamaría M, Silva-Bermúdez P, García-López J, Tecante A, Velasquillo C, et al. Polyelectrolyte complex of Aloe vera, chitosan, and alginate produced fibroblast and lymphocyte viabilities and migration. Carbohydr Polym. 2018;192:84-94.

19. Bigucci F, Luppi B, Cerchiara T, Sorrenti M, Bettinetti G, Rodriguez L, et al. Chitosan/pectin polyelectrolyte complexes: Selection of suitable preparative conditions for colon-specific delivery of vancomycin. Eur J Pharm Sci. 2008;35:435-41.

20. Maciel VB V., Yoshida CMP, Franco TT. Chitosan/pectin polyelectrolyte complex as a pH indicator. Carbohydr Polym. 2015;132:537-45.

21. Da Costa MPM, De Mello Ferreira IL, De Macedo Cruz MT. New polyelectrolyte complex from pectin/chitosan and montmorillonite clay. Carbohydr Polym. 2016;146:123-30. 
22. Neufeld L, Bianco-Peled H. Pectin-chitosan physical hydrogels as potential drug delivery vehicles. Int J Biol Macromol. 2017;101:852-61.

23. Andishmand H, Tabibiazar M, Mohammadifar MA, Hamishehkar H. Pectin-zinc-chitosanpolyethylene glycol colloidal nano-suspension as a food grade carrier for colon targeted delivery of resveratrol. Int J Biol Macromol. 2017;97:16-22.

24. Kulkarni N, Wakte P, Naik J. Development of floating chitosan-xanthan beads for oral controlled release of glipizide. Int J Pharm Investig. 2015;5(2):73-80.

25. Horn MM, Martins VCA, de Guzzi Plepis AM. Influence of collagen addition on the thermal and morphological properties of chitosan/xanthan hydrogels. Int J Biol Macromol. 2015;80:225-30.

26. Kim J, Hwang J, Seo Y, Jo Y, Son J, Choi J. Engineered chitosan-xanthan gum biopolymers effectively adhere to cells and readily release incorporated antiseptic molecules in a sustained manner. J Ind Eng Chem. 2017;46:68-79.

27. Shu G, He Y, Chen L, Song Y, Meng J, Chen H. Microencapsulation of Lactobacillus Acidophilus by xanthan-chitosan and its stability in yoghurt. Polymers. 2017;9(12):1-11.

28. Maciel DJ, Ferreira IL de M. Properties evaluation of polyelectrolyte complex based on iota carrageenan and chitosan in acidic and basic media. Mater Lett. 2018;229:142-7.

29. Volod'ko A V., Davydova VN, Nedashkovskaya OI, Terentieva NA, Chusovitin EA, Galkin NG, et al. Morphology, electrokinetic characteristics and the effect on biofilm formation of carrageenan:chitosan polyelectrolyte complexes. Int J Biol Macromol. 2018;117:1118-24.

30. Mahdavinia GR, Karimi MH, Soltaniniya M, Massoumi B. In vitro evaluation of sustained ciprofloxacin release from $\kappa$-carrageenan-crosslinked chitosan/hydroxyapatite hydrogel nanocomposites. Int J Biol Macromol. 2019;126:443-53.

31. Bigucci F, Abruzzo A, Vitali B, Saladini B, Cerchiara T, Gallucci MC, et al. Vaginal inserts based on chitosan and carboxymethylcellulose complexes for local delivery of chlorhexidine: Preparation, characterization and antimicrobial activity. Int J Pharm. 2015;478(2):456-63.

32. Cerchiara T, Abruzzo A, Parolin C, Vitali B, Bigucci F, Gallucci MC, et al. Microparticles based on chitosan/carboxymethylcellulose polyelectrolyte complexes for colon delivery of vancomycin. Carbohydr Polym. 2016;143:124-30.

33. Cho AR, Chun YG, Kim BK, Park DJ. Preparation of Chitosan-TPP Microspheres as Resveratrol Carriers. J Food Sci. 2014;79(4):568-76.

34. Bernabé P, Peniche C, Argüelles-Monal W. Swelling behavior of chitosan/pectin polyelectrolyte complex membranes. Effect of thermal cross-linking. Polym Bull. 2005;55(5):367-75.

35. Čalija B, Savic S, Krajišnik D, Daniels R, Vučen S, Markovic B, et al. PH-sensitive polyelectrolyte films derived from submicron chitosan/Eudragit ${ }^{\circledR}$ L 100-55 complexes: Physicochemical characterization and in vitro drug release. J Appl Polym Sci. 2015;132(39):1-9.

36. Wu Y, Ying Y, Liu Y, Zhang H, Huang J. Preparation of chitosan/poly vinyl alcohol films and their inhibition of biofilm formation against Pseudomonas aeruginosa PAO1. Int J Biol Macromol. 2018;118:2131-7.

37. Shu XZ, Zhu KJ. The release behavior of brilliant blue from calcium-alginate gel beads coated by chitosan: The preparation method effect. Eur J Pharm Biopharm. 2002;53(2):193-201. 
38. Pasparakis G, Bouropoulos N. Swelling studies and in vitro release of verapamil from calcium alginate and calcium alginate-chitosan beads. Int J Pharm. 2006;323(1-2):34-42.

39. Rodrigues S, Costa AMR Da, Grenha A. Chitosan/carrageenan nanoparticles: Effect of cross-linking with tripolyphosphate and charge ratios. Carbohydr Polym. 2012;89(1):282-9.

40. Čalija B, Milić J, Cekić N, Krajišnik D, Daniels R, Savić S. Chitosan oligosaccharide as prospective cross-linking agent for naproxen-loaded Ca-alginate microparticles with improved $\mathrm{pH}$ sensitivity. Drug Dev Ind Pharm. 2013;39(1):77-88.

41. Varga N, Benko M, Sebok D, Dékány I. BSA/polyelectrolyte core-shell nanoparticles for controlled release of encapsulated ibuprofen. Colloids Surfaces B Biointerfaces. 2014;123:616-22.

42. Lai WF, Shum HC. Hypromellose-graft-chitosan and its polyelectrolyte complex as novel systems for sustained drug delivery. ACS Appl Mater Interfaces. 2015;7(19):10501-10.

43. Lv X, Zhang W, Liu Y, Zhao Y, Zhang J, Hou M. Hygroscopicity modulation of hydrogels based on carboxymethyl chitosan/Alginate polyelectrolyte complexes and its application as $\mathrm{pH}$-sensitive delivery system. Carbohydr Polym. 2018;198:86-93.

44. Du J, Zhang S, Sun R, Zhang LF, Xiong CD, Peng YX. Novel polyelectrolyte carboxymethyl konjac glucomannan-chitosan nanoparticles for drug delivery. II. Release of albumin in vitro. J Biomed Mater Res (Part B Appl Biomater). 2005;72(2):299-304.

45. Du J, Dai J, Liu JL, Dankovich T. Novel pH-sensitive polyelectrolyte carboxymethyl Konjac glucomannan-chitosan beads as drug carriers. React Funct Polym. 2006;66(10):1055-61.

46. Naidu VGM, Madhusudhana K, Sashidhar RB, Ramakrishna S, Khar RK, Ahmed FJ, et al. Polyelectrolyte complexes of gum kondagogu and chitosan, as diclofenac carriers. Carbohydr Polym. 2009;76(3):464-71.

47. Bhatia M, Ahuja M. Psyllium arabinoxylan: Carboxymethylation, characterization and evaluation for nanoparticulate drug delivery. Int J Biol Macromol. 2015;72:495-501.

48. Dash M, Samal SK, Morelli A, Bartoli C, Declercq HA, Douglas TEL, et al. Ulvan-chitosan polyelectrolyte complexes as matrices for enzyme induced biomimetic mineralization. Carbohydr Polym. 2018;182:254-64.

49. Minkal, Ahuja M, Bhatt DC. Polyelectrolyte complex of carboxymethyl gum katira-chitosan: Preparation and characterization. Int J Biol Macromol. 2018;106:1184-91.

50. Yan JK, Wang YY, Qiu WY, Wu JY. Construction and characterization of nanosized curdlan sulfate/chitosan polyelectrolyte complex toward drug release of zidovudine. Carbohydr Polym. 2017;174:209-16.

51. Yan JK, Qiu WY, Wang YY, Wu LX, Cheung PCK. Formation and characterization of polyelectrolyte complex synthesized by chitosan and carboxylic curdlan for 5-fluorouracil delivery. Int J Biol Macromol. 2018;107:397-405.

52. Leonida M, Ispas-Szabo P, Mateescu MA. Self-stabilized chitosan and its complexes with carboxymethyl starch as excipients in drug delivery. Bioact Mater. 2018;3(3):334-40.

53. Jain D, Bar-Shalom D. Alginate drug delivery systems: Application in context of pharmaceutical and biomedical research. Drug Dev Ind Pharm. 2014;40(12):1576-84. 
54. Das RK, Kasoju N, Bora U. Encapsulation of curcumin in alginate-chitosan-pluronic composite nanoparticles for delivery to cancer cells. Nanomedicine Nanotechnology, Biol Med. 2010;6(1):153-60.

55. Abreu FOMS, Bianchini C, Forte MMC, Kist TBL. Influence of the composition and preparation method on the morphology and swelling behavior of alginate-chitosan hydrogels. Carbohydr Polym. 2008;74(2):283-9.

56. Cho AR, Chun YG, Kim BK, Park DJ. Preparation of alginate- $\mathrm{CaCl} 2$ microspheres as resveratrol carriers. J Mater Sci. 2014;49(13):4612-9.

57. George M, Abraham TE. Polyionic hydrocolloids for the intestinal delivery of protein drugs: Alginate and chitosan - a review. J Control Release. 2006;114:1-14.

58. Chan LW, Lee HY, Heng PWS. Mechanisms of external and internal gelation and their impact on the functions of alginate as a coat and delivery system. Carbohydr Polym. 2006;63(2):176-87.

59. Ribeiro AJ, Silva C, Ferreira D, Veiga F. Chitosan-reinforced alginate microspheres obtained through the emulsification/internal gelation technique. Eur J Pharm Sci. 2005;25(1):31-40.

60. Sæther HV, Holme HK, Maurstad G, Smidsrød O, Stokke BT. Polyelectrolyte complex formation using alginate and chitosan. Carbohydr Polym. 2008;74(4):813-21.

61. Wong TW, Chan LW, Kho S Bin, Sia Heng PW. Design of controlled-release solid dosage forms of alginate and chitosan using microwave. J Control Release. 2002;84(3):99-114.

62. Tavakol M, Vasheghani-Farahani E, Dolatabadi-Farahani T, Hashemi-Najafabadi S. Sulfasalazine release from alginate-N,O-carboxymethyl chitosan gel beads coated by chitosan. Carbohydr Polym. 2009;77(2):326-30.

63. Zhang Y, Wei W, Lv P, Wang L, Ma G. Preparation and evaluation of alginate-chitosan microspheres for oral delivery of insulin. Eur J Pharm Biopharm. 2011;77(1):11-9.

64. Elzatahry AA, Eldin MSM, Soliman EA, Hassan EA. Evaluation of alginate-chitosan bioadhesive beads as a drug delivery system for the controlled release of theophylline. J Appl Polym Sci. 2009;111(5):2452-9.

65. Wittaya-Areekul S, Kruenate J, Prahsarn C. Preparation and in vitro evaluation of mucoadhesive properties of alginate/chitosan microparticles containing prednisolone. Int J Pharm. 2006;312(12):113-8.

66. Nasti A, Zaki NM, De Leonardis P, Ungphaiboon S, Sansongsak P, Rimoli MG, et al. Chitosan/TPP and chitosan/TPP-hyaluronic acid nanoparticles: Systematic optimisation of the preparative process and preliminary biological evaluation. Pharm Res. 2009;26(8):1918-30.

67. Contreras-Ruiz L, De La Fuente M, García-Vázquez C, Sáez V, Seijo B, Alonso MJ, et al. Ocular tolerance to a topical formulation of hyaluronic acid and chitosan-based nanoparticles. Cornea. 2010;29(5):550-8.

68. Wadhwa S, Paliwal R, Paliwal SR, Vyas SP. Hyaluronic acid modified chitosan nanoparticles for effective management of glaucoma: Development, characterization, and evaluation. J Drug Target. 2010;18(4):292-302.

69. Kalam MA. Development of chitosan nanoparticles coated with hyaluronic acid for topical ocular delivery of dexamethasone. Int J Biol Macromol. 2016;89:127-36. 
70. Kalam MA. The potential application of hyaluronic acid coated chitosan nanoparticles in ocular delivery of dexamethasone. Int J Biol Macromol. 2016;89:559-68.

71. Luppi B, Bigucci F, Mercolini L, Musenga A, Sorrenti M, Catenacci L, et al. Novel mucoadhesive nasal inserts based on chitosan/hyaluronate polyelectrolyte complexes for peptide and protein delivery. J Pharm Pharmacol. 2009;61(2):151-7.

72. Lee SB, Lee YM, Song KW, Park MH. Preparation and Properties of Polyelectrolyte Complex Sponges Composed of Hyaluronic Acid and Chitosan and Their Biological Behaviors. J Appl Polym Sci. 2003;90(4):925-32.

73. Profire L, Pieptu D, Dumitriu RP, Dragostin O, Vasile C. Sulfadiazine modified CS/HA PEC destined to wound dressing. Rev medico-chirurgicală a Soc Medici şi Nat din Iaşi. 2013;117(2):525-31.

74. Dumitriu RP, Profire L, Nita LE, Dragostin OM, Ghetu N, Pieptu D, et al. Sulfadiazine-chitosan conjugates and their polyelectrolyte complexes with hyaluronate destined to the management of burn wounds. Materials. 2015;8(1):317-38.

75. Lalevée G, Sudre G, Montembault A, Meadows J, Malaise S, Crépet A, et al. Polyelectrolyte complexes via desalting mixtures of hyaluronic acid and chitosan-Physicochemical study and structural analysis. Carbohydr Polym. 2016;154:86-95.

76. Nath SD, Abueva C, Kim B, Lee BT. Chitosan-hyaluronic acid polyelectrolyte complex scaffold crosslinked with genipin for immobilization and controlled release of BMP-2. Carbohydr Polym. 2015;115:207-14.

77. Sriamornsak P. Application of pectin in oral drug delivery. Expert Opin Drug Deliv. 2011;8:100923.

78. Sinha VR, Kumria R. Polysaccharides in colon-specific drug delivery. Int J Pharm. 2001;224:19-38.

79. Yang L, Chu JS, Fix JA. Colon-specific drug delivery: New approaches and in vitro/in vivo evaluation. Int J Pharm. 2002;235:1-15.

80. Wong TW, Colombo G, Sonvico F. Pectin matrix as oral drug delivery vehicle for colon cancer treatment. AAPS PharmSciTech. 2011;12:201-14.

81. Munjeri O, Collett JH, Fell JT. Hydrogel beads based on amidated pectins for colon-specific drug delivery: The role of chitosan in modifying drug release. J Control Release. 1997;46(3):273-8.

82. Kim TH, Park YH, Kim KJ, Cho CS. Release of albumin from chitosan-coated pectin beads in vitro. Int J Pharm. 2003;250(2):371-83.

83. Hiorth M, Versland T, Heikkilä J, Tho I, Sande SA. Immersion coating of pellets with calcium pectinate and chitosan. Int J Pharm. 2006;308(1-2):25-32.

84. Das S, Chaudhury A, Ng KY. Preparation and evaluation of zinc-pectin-chitosan composite particles for drug delivery to the colon: Role of chitosan in modifying in vitro and in vivo drug release. Int $\mathrm{J}$ Pharm. 2011;406(1-2):11-20.

85. Li L, Ni R, Shao Y, Mao S. Carrageenan and its applications in drug delivery. Carbohydr Polym. 2014;103(1):1-11.

86. Grenha A, Gomes ME, Rodrigues M, Santo VE, Mano JF, Neves NM, et al. Development of new chitosan/carrageenan nanoparticles for drug delivery applications. J Biomed Mater Res (Part A). 2010;92(4):1265-72. 
87. Kumar A, Rao KM, Han SS. Application of xanthan gum as polysaccharide in tissue engineering: A review. Carbohydr Polym. 2018;180:128-44.

88. Popa N, Novac O, Profire L, Lupusoru CE, Popa MI. Hydrogels based on chitosan-xanthan for controlled release of theophylline. J Mater Sci Mater Med. 2010;21(4):1241-8.

89. de Morais Lima M, Carneiro LC, Bianchini D, Dias ARG, Zavareze E da R, Prentice C, et al. Structural, Thermal, Physical, Mechanical, and Barrier Properties of Chitosan Films with the Addition of Xanthan Gum. J Food Sci. 2017;82(3):698-705.

90. Gun'ko VM, Savina IN, Mikhalovsky S V. Cryogels: Morphological, structural and adsorption characterisation. Adv Colloid Interface Sci. 2013;(187-188):1-46.

91. Kumar S, Kaur P, Bernela M, Rani R, Thakur R. Ketoconazole encapsulated in chitosan-gellan gum nanocomplexes exhibits prolonged antifungal activity. Int J Biol Macromol. 2016;93:988-94.

92. Chen H, Fan M. Novel thermally sensitive pH-dependent chitosan/carboxymethyl cellulose hydrogels. J Bioact Compat Polym. 2008;23(1):38-48.

93. Lee MH, Chun MK, Choi HK. Preparation of Carbopol/chitosan interpolymer complex as a controlled release tablet matrix; Effect of complex formation medium on drug release characteristics. Arch Pharm Res. 2008;31(7):932-7.

94. Lu Z, Chen W, Hamman J. Chitosan-Polycarbophil Complexes in Swellable Matrix Systems for Controlled Drug Release. Curr Drug Deliv. 2007;4(4):257-63.

95. He M, Shi L, Wang G, Cheng Z, Han L, Zhang X, et al. Biocompatible and biodegradable chitosan/sodium polyacrylate polyelectrolyte complex hydrogels with smart responsiveness. Int $\mathrm{J}$ Biol Macromol. 2019; doi: 10.1016/j.ijbiomac.2019.11.092

96. Moustafine RI, Margulis EB, Sibgatullina LF, Kemenova VA, Mooter G Van den. Comparative evaluation of interpolyelectrolyte complexes of chitosan with Eudragit ${ }^{\circledR}$ L100 and Eudragit $\AA$ L10055 as potential carriers for oral controlled drug delivery. Eur J Pharm Biopharm. 2008;70(1):215-25.

97. Sareen R, Jain N, Rajkumari A, Dhar KL. PH triggered delivery of curcumin from Eudragit-coated chitosan microspheres for inflammatory bowel disease: Characterization and pharmacodynamic evaluation. Drug Deliv. 2016;23(1):55-62.

98. Koyano T, Koshizaki N, Umehara H, Nagura M, Minoura N. Surface states of PVA/chitosan blended hydrogels. Polymer. 2000;41(12):4461-5.

99. Sugimoto K, Yoshida M, Yata T, Higaki K, Kimura T. Evaluation of poly(vinyl alcohol)-gel spheres containing chitosan as dosage form to control gastrointestinal transit time of drugs. Biol Pharm Bull. 1998;21(11):1202-6.

100. Cascone MG, Maltinti S. Hydrogels based on chitosan and dextran as potential drug delivery systems. J Mater Sci Mater Med. 1999;10(5):301-7.

101. Cheaburu-Yilmaz CN, Yilmaz O, Kose FA, Bibire N. Chitosan-graft-poly(Nisopropylacrylamide)/PVA cryogels as carriers for mucosal delivery of voriconazole. Polymers. 2019;11(9):1-20. 


\title{
Biokompatibilni nekovalentni kompleksi hitozana sa različitim polimerima: svojstva i primena kao nosača lekovitih supstanci
}

\author{
Ana Ćirić ${ }^{1^{*}}$, Danina Krajišnik ${ }^{1}$, Bojan Čalija ${ }^{1}$, Ljiljana Đekić $^{1}$ \\ ${ }^{1}$ Univerzitet u Beogradu - Farmaceutski fakultet, Katedra za farmaceutsku tehnologiju i \\ kozmetologiju, Vojvode Stepe 450, 11221 Beograd, Srbija \\ *Autor za korespondenciju: Ana Ćirić, E-mail: ana.ciric001@gmail.com
}

\section{Kratak sadržaj}

Formulacija biokompatibilnih nosača lekovitih supstanci na bazi katjonskog biopolimera hitozana i prirodnih ili sintetskih polimera predstavlja značajan istraživački interes. Stoga je cilj ovog rada sagledati njihovu potencijalnu primenu kao nosača lekovitih supstanci. Najistraženije blende polimera na bazi hitozana su polielektrolitni kompleksi (PEK) dobijeni uspostavljanjem jonskih interakcija sa biokompatibilnim polianjonima, npr. alginatom, pektinom, ksantan gumom, karagenanom, karboksimetilcelulozom i kolagenom. U zavisnosti od uslova pripreme, mogu se formulisati PEK u vidu membrana/filmova, hidrogelnih perli, nanočestica, mikročestica ili drugih tipova nosača, sa ciljem postizanja kontrolisanog (npr. produženog, odloženog, kolon-specifičnog i pH-zavisnog) oslobađanja lekovitih supstanci. PEK su pogodni za inkapsulaciju hidrofilnih ili lipofilnih lekovitih supstanci različitih molekulskih masa. Inkapsulacija obezbeđuje očuvanje njihove strukture, aktivnosti, poboljšanje apsorpcije, smanjenje štetnih efekata i dugoročnu stabilnost in vitro i in vivo. Biokompatibilne strukture nalik kompleksima na bazi hitozana mogu se formirati i uspostavljanjem vodoničnih veza, kao što je slučaj sa polivinil alkoholom. Njihovo bubrenje ne zavisi od pH. Inkapsulirane lekovite supstance se najčešće oslobađaju prema nekom od već poznatih tipova difuzije. Dodatno, različiti derivati hitozana (npr. karboksimetilhitozan, trimetilhitozan, akril derivati hitozana) sintetisani su radi poboljšanja rastvorljivosti polimera u vodi u širokom opsegu $\mathrm{pH}$ i povećanja kapaciteta za inkapsulaciju lekovitih supstanci tako dobijenih PEK, koji takođe predstavljaju obećavajuće nosače.

Ključne reči: hitozan, polielektrolitni kompleks, biokompatibilnost, nosači lekovitih supstanci, kontrolisano oslobađanje lekovitih supstanci 